\title{
Inflammatory responses induced by Helicobacter pylori on the carcinogenesis of gastric epithelial GES-1 cells
}

\author{
JIANJUN WANG $^{1 *}$, YONGLIANG YAO ${ }^{1 *}$, QINGHUI ZHANG ${ }^{1}$, \\ SHASHA LI ${ }^{1}$ and LIJUN TANG ${ }^{2}$ \\ ${ }^{1}$ Department of Clinical Laboratory, Kunshan First People's Hospital, \\ Affiliated to Jiangsu University, Kunshan, Jiangsu 215300; \\ ${ }^{2}$ Molecular Biology Research Center, School of Life Science, \\ Central South University, Changsha, Hunan 410078, P.R. China
}

Received October 19, 2018; Accepted January 1, 2019

DOI: $10.3892 /$ ijo.2019.4775

\begin{abstract}
Helicobacter pylori $(H P)$ is a pathogenic bacterium associated with chronic gastritis, gastric ulcer and gastric cancer. In the present study, the primary carcinogenesis process of normal gastric epithelial cells (GES-1) infected with $H P$ was investigated. It was determined that infected gastric mucosal epithelial GES-1 cells secreted increased interleukin-8 (IL-8) and IL-23, and exhibited enhanced expression of inducible nitric oxide synthase and cyclooxygenase-2, inducing inflammatory reactions and resulting in apoptosis. The bacterial infection significantly increased the expression of carcinogenesis-associated genes, including p16, c-Myc, p53 and p21, as well as the expression of cell surface signaling molecules cluster of differentiation 44 (CD44) and CD54 in GES-1 cells or tissues of patients with gastritis and gastric cancer in vitro or in vivo. Simultaneously, the migration and invasion abilities of normal gastric epithelial GES-1 cells were increased following HP infection. These observations demonstrated that the inflammatory response of $H P$ infection could cause normal gastric epithelial cells to undergo significant cancerous reactions, indicating that $H P$ is a risk factor for gastric cancer.
\end{abstract}

\section{Introduction}

Helicobacter pylori $(H P)$ is etiologically active in the occurrence of gastric cancer, stomach inflammation and peptic ulcer disease (1), infecting $\sim 50 \%$ of the whole global

Correspondence to: Dr Lijun Tang, Molecular Biology Research Center, School of Life Science, Central South University, 110 Xiangya Road, Kaifu, Changsha, Hunan 410078, P.R. China

E-mail: tljxie@csu.edu.cn

${ }^{*}$ Contributed equally

Key words: Helicobacter pylori, gastric cancer, carcinogenesis, inflammation, apoptosis population in 2015 (2). In cases of chronic or acute $H P$ infection, inflammation is a major cause of peptic ulcer disease and gastric malignancy (3). The pathogenesis of gastric cancer is multi-factorial, with $H P$ infection being the probable leading cause (4). The International Agency for Research on Cancer, World Health Organization in 1994 defined HP as a class I carcinogen and a cause of human cancer (5). Studies on $H P$ infection in rodents have independently provided evidence of the role of the bacterial pathogen in gastric cancer development (6-8). A previous study reported $H P$ as the single leading risk factor of gastric cancer development and is estimated to cause $\sim 75 \%$ of all cases of gastric cancer globally in 2015 (9).

Long-term inflammation has been demonstrated to intensify gastric barrier penetrability, further injure lamina propria (10) and potentially contribute to numerous extra-gastric dysfunctions (11-13). HP utilizes virulence factors in gastric epithelial cells to target the signaling pathways that modulate cell cycle, apoptosis and other special survival processes (14). Among the several reported $H P$ factors involved in gastric lining disturbance, the most studied virulence factors include cag pathogenicity island (cagPAI) and vacuolating cytotoxin gene (vacA) (15). CagPAI encodes a type IV secretion system, which is activated in human cancer through the deliverance of the oncoprotein cytotoxin-associated gene A ( CagA) into host cells. Chronic inflammation due to the virulence factor CagA is considered to be the mechanism of $H P$-associated gastric cancer occurrence (16). However, the mechanisms of tissue damage caused by the aforementioned factors remain unknown.

The present study focused on experiments on the carcinogenesis of $H P$ infection in normal gastric epithelial cells and investigated the specific molecular mechanisms of carcinogenesis in the $H P$-infected GES-1 cells.

\section{Materials and methods}

GES-1 cell culture. Normal epithelial GES-1 cells of human gastric mucosa (Cell Resource Center of Shanghai Academy of Sciences, Chinese Academy of Sciences, Shanghai, China) were cultured in wells or flasks at $37^{\circ} \mathrm{C}$ in 
an atmosphere containing $5 \% \mathrm{CO}_{2}$ in Dulbecco's modified Eagle's medium (DMEM; GE Healthcare Life Sciences, Little Chalfont, UK). The medium contained $10 \%(\mathrm{v} / \mathrm{v})$ fetal bovine serum (FBS; GE Healthcare Life Sciences), $0.25 \mu \mathrm{g} / \mathrm{ml}$ amphotericin $\mathrm{B}, 0.1 \mathrm{mg} / \mathrm{ml}$ streptomycin and $100 \mathrm{U} / \mathrm{ml}$ penicillin.

HP culture. The wild-type HP strain 26695 was obtained from the Chinese Center for Disease Control and Prevention (Beijing, China). $H P$ was cultured for $72 \mathrm{~h}$ at $37^{\circ} \mathrm{C}$ in an atmosphere containing $5 \% \mathrm{CO}_{2}$ on commercial $\mathrm{HP}$ culture plates.

GES-1 and HP co-culture. Following washing once with PBS, GES-1 cells were placed in 6-well plastic plates at a density of $3 \times 10^{5}$ cells/well in $1 \mathrm{ml}$ FBS-free DMEM. HP was restored by a swab from the agar plates and suspended in DMEM at an optical density of 0.6 at $600 \mathrm{~nm}$, which corresponded to $3 \times 10^{6}$ colony-forming $\mathrm{U} / \mathrm{ml}$. The $H P$ was added to cells in DMEM without FBS and antibiotics at a multiplicity of infection (MOI) of 100:1, and co-cultured at $37^{\circ} \mathrm{C}$ and $5 \% \mathrm{CO}_{2}$ for 24 or $48 \mathrm{~h}$. The morphology of $H P$-infected GES-1 cells was observed by Olympus CKX53 Inverted Fluorescence Microscope (magnification, x40; Olympus Corporation, Tokyo, Japan).

Apoptosis assay. Apoptosis was measured using an Annexin V-FITC Apoptosis Detection kit (BD Biosciences; Becton, Dickinson and Company, Franklin Lakes, NJ, USA), according to the manufacturer's protocols and analyzed by FlowJo 7.6 software (Tree Star, Inc., Ashland, OR, USA). Specifically, following washing twice with PBS, cells were re-suspended in $100 \mu \mathrm{l} 1 \mathrm{X}$ binding buffer (BD Biosciences; Becton, Dickinson and Company), and then incubated for 15 min with fluorescein isothiocyanate Annexin $\mathrm{V}$ and propidium iodide (each $5 \mu \mathrm{l}$; BD Biosciences; Becton, Dickinson and Company) at $37^{\circ} \mathrm{C}$ in the dark. Subsequently, $400 \mu 11 \mathrm{X}$ binding buffer was added to each tube, followed by detection on a FACS Canto II flow cytometer (BD Biosciences; Becton, Dickinson and Company).

Reverse transcription quantitative polymerase chain reaction (RT-qPCR). The primers of $\beta$-actin, cyclooxygenase-2 (COX-2), inducible nitric oxide synthase (iNOS), p16, c-Myc, p53 and p21 designed by Primer Premier 5.0 (Premier Biosoft, Palo Alto, CA, USA) and primers sequences were purchased from Invitrogen (Thermo Fisher Scientific, Inc., Waltham, MA, USA).

Total RNA was isolated from HP-infected GES-1 cells using a TRIzol ${ }^{\circledR}$ reagent (Thermo Fisher Scientific, Inc.) and detected spectrophotometrically. The cDNA was prepared using M-MLV reverse transcriptase (Promega Corporation, Madison, WI, USA). A mixture consisting of RNA (500 ng/ $\mu \mathrm{l}$; $2 \mu \mathrm{l}), 5 \mathrm{X}$ M-MLV RT buffer $(12 \mu \mathrm{l})$, dNTP mixes $(2.5 \mathrm{mM}$; $6 \mu 1$ ), RNase inhibitor (30 U/ $/ \mu 1 ; 1 \mu \mathrm{l}), \mathrm{M}-\mathrm{MLV}$ RT (5 U/ $\mu 1$; $4 \mu \mathrm{l})$, Oligo dT(18) primer (500 $\mathrm{ng} / \mu \mathrm{l} ; 3 \mu \mathrm{l})$ and diethyl pyrocarbonate water $(17 \mu \mathrm{l})$ was cultured at $37^{\circ} \mathrm{C}$ for $1 \mathrm{~h}$. RT-qPCR was performed on an Eppendorf PCR system (Eppendorf, Hamburg, Germany). cDNA (1 $\mu \mathrm{l})$, forward and reverse primers (each $0.5 \mu \mathrm{l}), \mathrm{SYBR}^{\circledR}$ Premix ExTaq $(8 \mu \mathrm{l}$;
Takara Biotechnology Co., Ltd., Dalian, China) and $\mathrm{dd}_{2} \mathrm{O}$ $(9 \mu 1)$ were added to the mix, followed by 32 cycles of amplification as follows: Denaturation at $94^{\circ} \mathrm{C}$ for $2 \mathrm{~min} ; 32$ cycles of $94^{\circ} \mathrm{C}$ for $20 \mathrm{sec}, 55^{\circ} \mathrm{C}$ for $35 \mathrm{sec}, 72^{\circ} \mathrm{C}$ for $25 \mathrm{sec}$; and extension at $72^{\circ} \mathrm{C}$ for $5 \mathrm{~min}$. The following primers were used: iNOS, forward, 5'-GAG-CTTCTACCTCAAGCTATC-3', and reverse, 5'-CCTGATGTTGCCATTGTTGGT-3'; COX-2, forward, 5'-AGATCATCTCTGCCTGAGTATCTT-3', and reverse, 5'-TTCAAATGAGATTGTGGGAAAATTGCT-3'; p21, forward, 5'-CCATGATGTTGATGCCCTAC-3', and reverse, 5'-TTGCCTGCCTTCCTTTCT-3'; p53, forward, 5'-CAGTCTACCTCCCGCCATAA-3', and reverse, 5'-CTCCCAAACATCCCTCACAG-3'; c-Myc, forward, 5'-GGGCTTTATCTAACTCGCTGTA-3', and reverse, 5'-GCTATGGGCAAAGTTTCGTG-3'; p16, forward, 5'-GAAGAAAGAGGAGGGGCTGG-3', and reverse, 5'-CTGCAGACCCTCTACCCACC-3'; and $\beta$-actin, forward, 5'-CCTGGCACCCAGCACAAT-3', and reverse, 5'-GCTGATCCACATCTGCTGGAA-3'. Subsequently, fluorescence was detected. Specific amplification was guaranteed by dissociation curves. Each sample was tested in triplicate, and the mean $\mathrm{Cq}$ value was calculated (17).

Western blotting. The GES-1 cells from each group were collected, washed with PBS twice on ice and incubated with a Radioimmunoprecipitation Assay protein lysate (Beyotime Institute of Biotechnology, Beijing, China; cat. no. P0013B) containing $1 \%$ benzene sulfonyl fluoride for $30 \mathrm{~min}$ at $4^{\circ} \mathrm{C}$. The protein concentration in the supernatant was then measured with a BCA protein concentration kit (Beyotime Institute of Biotechnology; cat. no. P0010). Proteins (30 $\mu \mathrm{g})$ were treated by $10 \%$ SDS-PAGE electrophoresis and transferred onto polyvinylidene difluoride membranes. The membranes were then immunoblotted with primary antibodies against $\beta$-actin (dilution, 1:2,000; cat. no. MAB8929), Cox-2 (dilution, 1:1,000; cat. no. AF4198), iNOS (dilution, 1:1,200; cat. no. MAB9502), p16 (dilution, 1:800; cat. no. AF5779), c-Myc (dilution, 1:1,000; cat. no. MAB3696), p53 (dilution, 1:1,600; cat. no. AF1355) and p21 (dilution, 1:1,000; cat. no. AF1047; R\&D Systems, Inc., Minneapolis, MN, USA) overnight at $4^{\circ} \mathrm{C}$, followed by cultivation with goat IgG horseradish peroxidase-conjugated antibody (R\&D Systems, Inc.; dilution, 1:1,000; cat. no. HAF019) at $37^{\circ} \mathrm{C}$ for $60 \mathrm{~min}$ and Enhanced Chemiluminescence Western Blotting Detection reagents (cat. no. RPN2209; GE Healthcare Life Sciences). The bands were visualized using a LAS-4000 system (GE Healthcare Life Sciences) and were analyzed quantitatively using ImageJ v1.8.0 software (National Institutes of Health, Bethesda, MD, USA).

Cytokine quantification by ELISA. GES-1 cells cultured in 6-well plates were processed in lipopolysaccharide (LPS; 50 ng/ml; Beijing Solarbio Science \& Technology Co., Ltd., Beijing, China; cat. no. L8880) or HP (MOI of 100) medium for 24 or $48 \mathrm{~h}$. The concentration of interleukin-8 (IL-8) and IL-23 in supernatants of stimulated cells was detected by IL-8 ELISA kit and IL-23 ELISA kits (Wuhan Boster Biological Technology, Ltd., Wuhan, China; cat. nos. EK0413 and EK1612, respectively), according to the manufacturer's protocols. Cytokine concentrations were determined by a standard curve. 
Wound-healing and Matrigel assays in vitro. Following 24 or $48 \mathrm{~h}$ of culture at $37^{\circ} \mathrm{C}$, the GES-1 cells were transferred using trypsinization, counted and seeded at $1 \times 10^{5}$ cells $/ \mathrm{ml}$ into 6 -well plates, followed by overnight culture at $37^{\circ} \mathrm{C}$ to form confluent single layers. Wounds were then induced using a $100 \mu \mathrm{l}$ pipette tip and imaged at 0,24 or $48 \mathrm{~h}$ under Olympus CKX53 Inverted Fluorescence Microscope at magnification, x100. The migration distance of the monolayer from the wounded area during this time period was detected and expressed as a migration index (the migrating distance following a stimulus relative to that of control cells). Each assay was conducted in triplicate and repeated at least five times.

Invasion assays were conducted in vitro, using Transwell plates (Costar; Corning, Inc., Corning, NY, USA) with $8-\mu \mathrm{m}$ pores. After $2 \times 10^{4} \mathrm{GES}-1$ cells were processed in LPS $(50 \mathrm{ng} / \mathrm{ml})$ or HP (MOI of 100) medium for $48 \mathrm{~h}$, they were added to the upper chamber of Transwell plates with Matrigel (Costar; Corning, Inc.) and DMEM in the lower chamber of Transwell plate contained with 5\% FBS. Following 24 or $48 \mathrm{~h}$ incubation, cells on the upper surface were removed using cotton wool and cells attached to the bottom were fixed with $75 \%$ methanol at $37^{\circ} \mathrm{C}$ for $15 \mathrm{~min}$ and stained with $0.5 \%$ crystal violet at $37^{\circ} \mathrm{C}$ for $30 \mathrm{~min}$. Images were captured and the cells were counted using Olympus CKX53 Inverted Fluorescence Microscope at x200 magnification.

Flow cytometry. GES-1 cultivated in 6-well plates were infected with $H P$ for 24 or $48 \mathrm{~h}$, and then harvested and rinsed twice with PBS containing $0.2 \%$ bovine serum albumin (cat. no. B7542; Sigma-Aldrich; Merck KGaA, Darmstadt, Germany). Following being stained with phycoerythrin-labeled monoclonal cluster of differentiation 44 (CD44; dilution, 1:200; cat. no. 562818; BD Biosciences; Becton, Dickinson and Company) or allophycocyanin-labeled CD54 (dilution, 1:200; cat. no. 559771; BD Biosciences; Becton, Dickinson and Company) antibodies or the isotype controls (dilution, 1:200; cat. no. 560787; BD Biosciences; Becton, Dickinson and Company) at $37^{\circ} \mathrm{C}$ for $30 \mathrm{~min}$, the cells were washed twice with PBS and fixed in $10 \%(\mathrm{v} / \mathrm{v})$ formaldehyde-PBS at $37^{\circ} \mathrm{C}$. Finally, cells were sorted and analyzed using a BD FACSCalibur with four-color fluorescence detection system (BD Biosciences; Becton, Dickinson and Company). Statistical data were analyzed by FlowJo 7.6 software. Mean fluorescence intensity and the percentage of positive cells were estimated after the values for the isotype controls were subtracted.

Immunohistochemical (IHC) analysis. Tissues from 6 normal male patients, 6 male patients with $\mathrm{HP}^{+}$gastritis and 6 male patients with $\mathrm{HP}^{+}$gastric cancer (stomach adenocarcinoma) aged 32-65 years (mean \pm SD, 44.3 \pm 8.9 years) were collected from Chongqing Cancer Institute (Chongqing, China) or Kunshan First People's Hospital Affiliated to Jiangsu University (Suzhou, China) from January 2013 and January 2017. The HP infection status of normal patients, patients with gastritis and patients with gastric cancer was confirmed by a Carbon 13 breathing experiment because this experiment could indicate that individuals were suffering from HP infection. All protocols were approved by the Ethics Committee of the
Chinese Hospital Association (Beijing, China) and written informed consent was provided by all participants in all experiments.

CD44 and CD54 in the membrane of gastric tissue cells from different participants were analyzed with an IHC assay. Briefly, all tissues were fixed with $4 \%$ formaldehyde (Beyotime Institute of Biotechnology; cat. no. P0099) at $37^{\circ} \mathrm{C}$ for $30 \mathrm{~min}$, and then were embedded in paraffin and cut into slices with a histotome. Following xylene-deparaffinizing and rehydration through AR grade absolute ethanol to distilled water at $37^{\circ} \mathrm{C}$, the 5 -mm-thick microarray sections were stained with Hydrogen Peroxide Block (cat. no. ab64218; Abcam, Cambridge, UK). Following cultured with rabbit anti-CD44 (dilution, 1:100; cat. no. 550392; BD Biosciences; Becton, Dickinson and Company) and anti-CD54 antibodies (dilution, 1:100; cat. no. BBA17; R\&D Systems, Inc.) at $37^{\circ} \mathrm{C}$ for $40 \mathrm{~min}$, the sections were washed with PBS three times and cultivated with Biotin goat anti-rabbit IgG (dilution, 1:100; cat. no. 550338; BD Biosciences; Becton, Dickinson and Company) for $30 \mathrm{~min}$ at $37^{\circ} \mathrm{C}$. Subsequently, following colorization with 3,3'-diaminobenzidine, the nuclei were counterstained lightly with hematoxylin at $37^{\circ} \mathrm{C}$. Images were captured and the cells were counted using Olympus CKX53 Inverted Fluorescence microscope, at magnification, $x 200$. The immunostained sections were evaluated by two independent pathologists.

Statistical analysis. Results from three independent experiments are presented as the mean \pm standard error of the mean (SEM). Data were processed on SPSS 16.0 for Windows (SPSS,Inc., Chicago, IL, USA) and tested using one-way analysis of variance (ANOVA). The one-way ANOVA and post-hoc Tukey's test were conducted on GraphPad Prism 6 (GraphPad Software, Inc., La Jolla, CA, USA) based on an assumption of normal distribution. $\mathrm{P}<0.05$ was considered to indicate a statistically significant difference.

\section{Results}

Apoptosis of HP-infected GES-1 cells. To investigate the effects of $H P$ on cell survival and physiology, the morphology and viability of $H P$-infected GES-1 cells was analyzed by microscopy and flow cytometry, respectively (Fig. 1). In vitro, the majority of GES-1 cells were in good condition, and only a small portion underwent $H P$ infection-induced apoptosis, indicating that the virulence factor toxicity of $H P$ could induce extensive apoptosis.

Inflammation-associated genes and proteins iNOS and COX-2 in GES-1 cells influenced by HP. The host cells employ reactive oxygen species and nitric oxide to eliminate an invading pathogen, but this reaction mechanism could also regulate the inflammatory response of host cells (18). A total of 2 major enzymes (iNOS and COX-2) involved in the metabolism of $\mathrm{HP}$-infected GES-1 cells (Fig. 2) were therefore examined using RT-qPCR and western blotting. The gray of bands was scanned on Image J, with $\beta$-actin as the standard. The gene and protein expression of iNOS and COX-2 were determined to be upregulated following infection. 
A
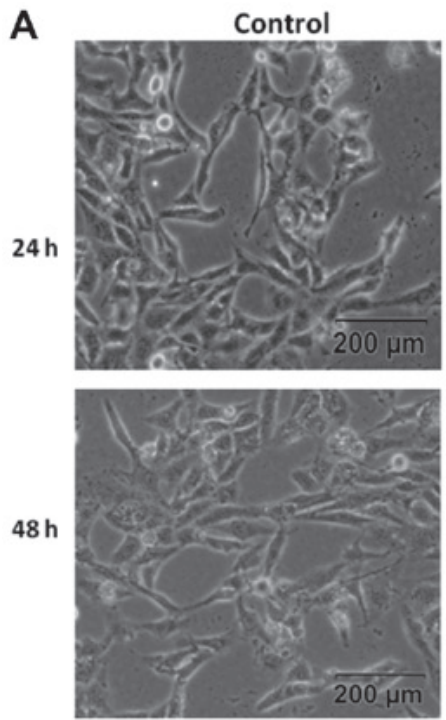

B
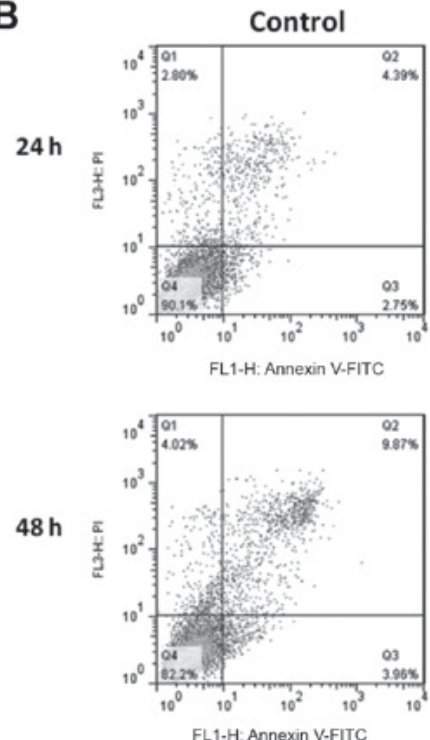

FL1-H:Annexin V-FITC
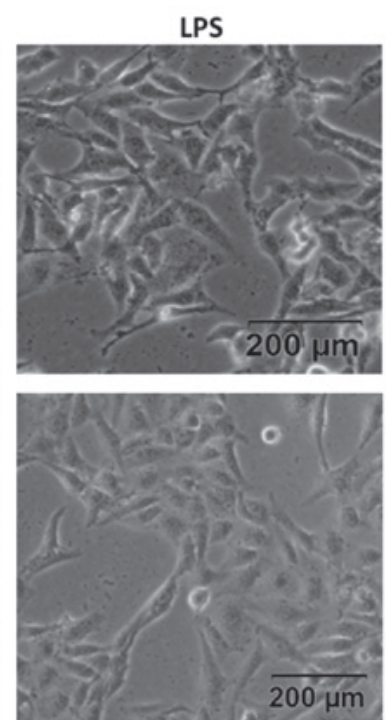

LPS
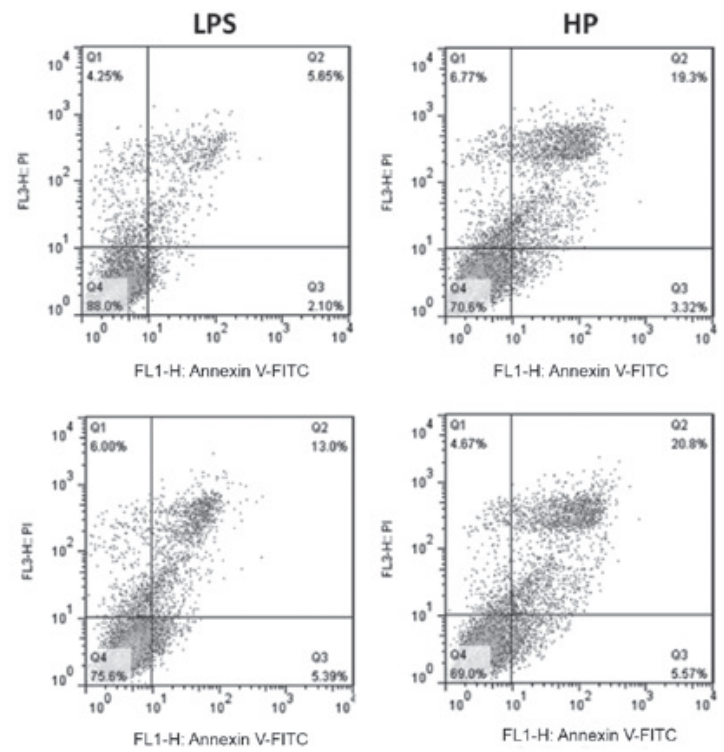

C

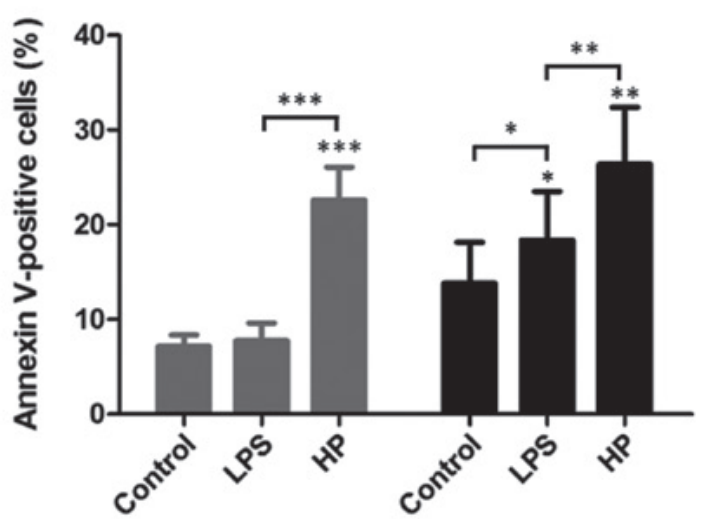

$24 \mathrm{~h}$

$48 \mathrm{~h}$

Figure 1. Apoptosis analysis of GES-1 cells infected with HP detected by microscope and flow cytometry. (A) Morphological characterization of GES-1 cells stimulated with LPS or $H P$ medium for 24 or $48 \mathrm{~h}$. Scale bar, $200 \mu \mathrm{m}$. (B) Flow cytometry results of GES-1 cells treated with LPS or $H P$ for 24 or $48 \mathrm{~h}$. (C) Quantification of apoptosis. Results presented as the mean \pm standard error of the mean. $n=3$, results are representative of three separate experiments $\left({ }^{*} \mathrm{P}<0.05\right.$ vs. control or LPS, ${ }^{* *} \mathrm{P}<0.01$ vs. control and ${ }^{* * *} \mathrm{P}<0.001$ vs. control or LPS). LPS, lipopolysaccharides; HP, Helicobacter pylori; FITC, fluorescein isothiocyanate; PI, propidium iodide.

Inflammatory factors $I L-8$ and IL-23 regulated by $H P$. Since immune cells are the main secretor of cytokines, the inflammatory response capacity of GES-1 cells following $H P$ infection was detected by measuring inflammatory factors (IL-8 and IL-23) in the supernatant using ELISA (Fig. 3). IL-8 and IL-23 levels were significantly increased in infected 
A
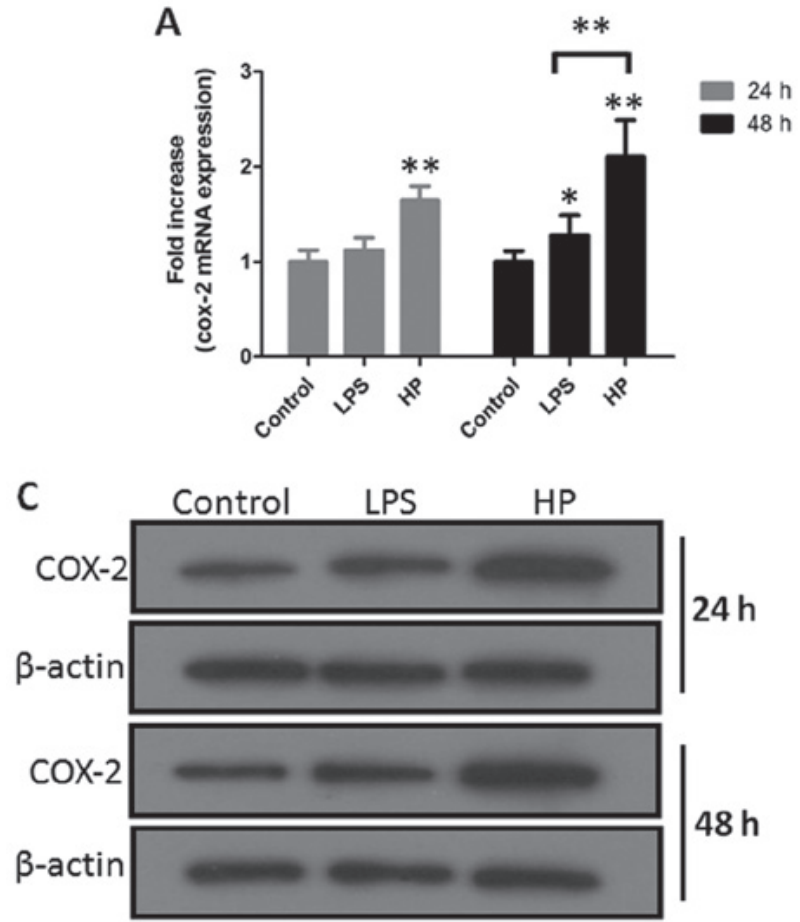

B
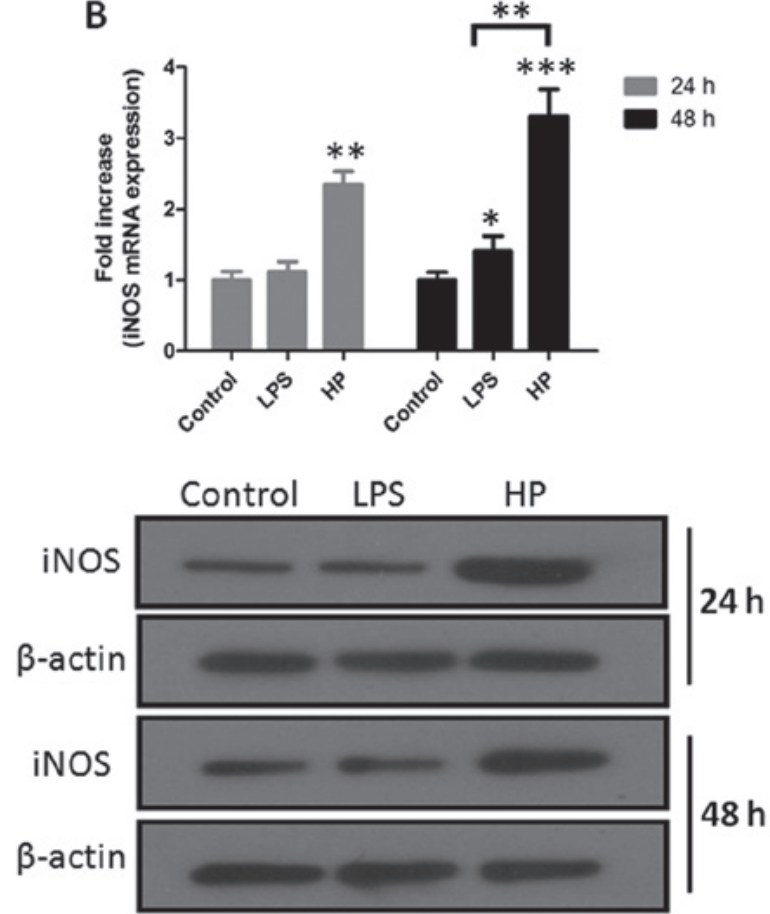

Figure 2. Expression of COX-2 and iNOS in GES-1 cells infected with $H P$ for 24 or 48 h from the gene and protein levels. Total mRNAs of (A) COX-2 and (B) iNOS isolated from $H P$-infected GES-1 cells were analyzed using reverse transcription-quantitative polymerase chain reaction. (C) Western blotting results of COX-2 and iNOS proteins in GES-1 cells infected with $H P$ for 24 or 48 h. Quantification of COX-2 and iNOS expression were conducted and data are presented as the mean \pm standard error of the mean of three independent experiments $\left({ }^{*} \mathrm{P}<0.05\right.$ vs. control, ${ }^{* *} \mathrm{P}<0.01$ vs. control or LPS and ${ }^{* * *} \mathrm{P}<0.001$ vs. control). LPS, lipopolysaccharides; HP, Helicobacter pylori; COX-2, cyclooxygenase-2; iNOS, inducible nitric oxide synthase.
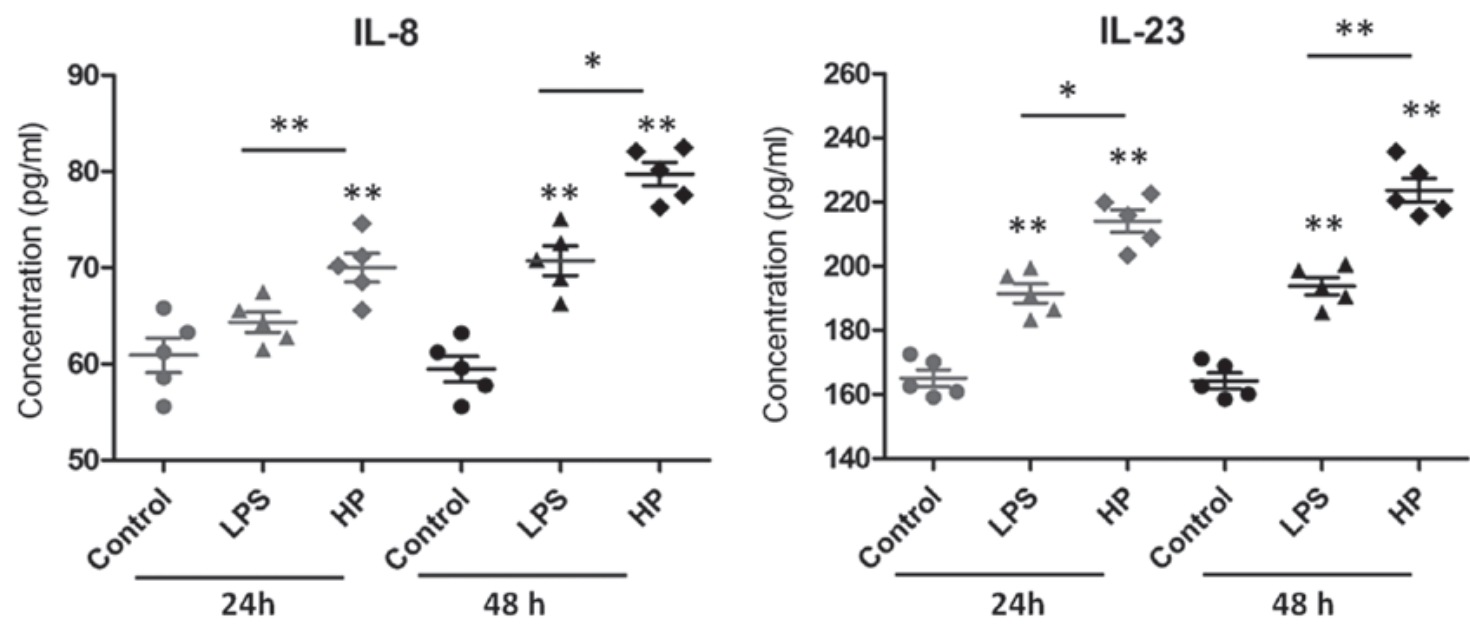

Figure 3. IL-8 and IL-23 in the supernatants of GES-1 cells treated with LPS and $H P$ for 24 or $48 \mathrm{~h}$ were determined by ELISA. Each symbol per condition represents the data obtained from one test. Horizontal lines represent the median values of 5 experiments (" $\mathrm{P}<0.05$ vs. LPS and ${ }^{* *} \mathrm{P}<0.01$ vs. control or LPS). LPS, lipopolysaccharides; HP, Helicobacter pylori; IL, interleukin.

cells, compared with the control or LPS-treated groups. These results indicated that normal gastric mucosal cells can also secrete a number of cytokines to inflammatorily respond to and resist the bacterial invasion.

Expression of cell carcinoma-associated genes and proteins induced by HP. Since long-term repeated HP infection could induce chronic gastritis, gastric ulcer or gastric cancer, the expression of cancer-associated genes and proteins, including p16, c-Myc, p53 and p21, was analyzed in HP-infected GES-1 cells using RT-qPCR and western blotting (Fig. 4). It was determined that the gene and protein expression levels of p16, c-Myc, p53 and p21 were all enhanced following HP infection, compared with the control or LPS-treated groups, indicating that $H P$ may be a risk factor of gastric cancer.

Cell migration and invasion capabilities of HP-infected GES-1. Since HP infection could change the expression of cancer-associated genes, causing the host cells to become cancerous, the cell migration and invasion abilities of 
A
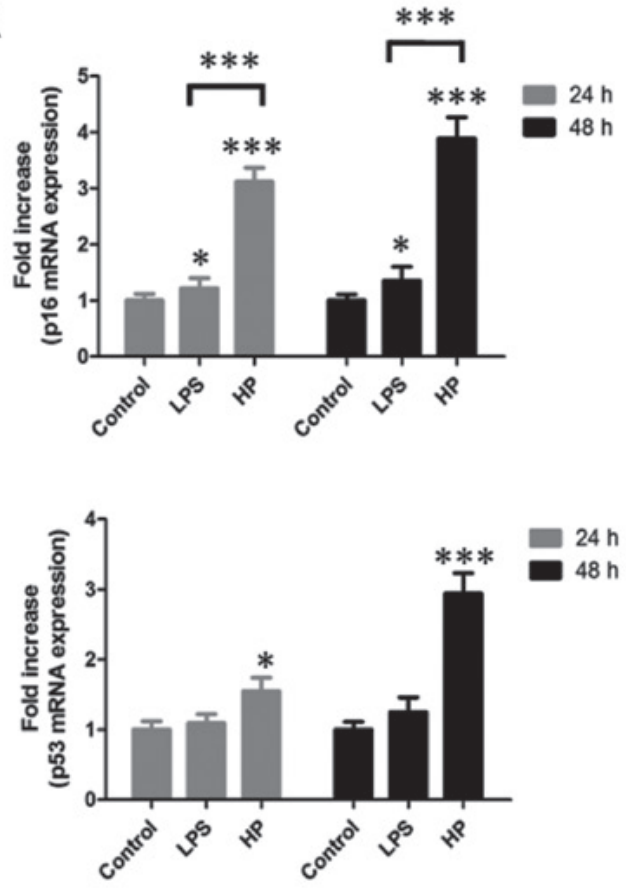

B
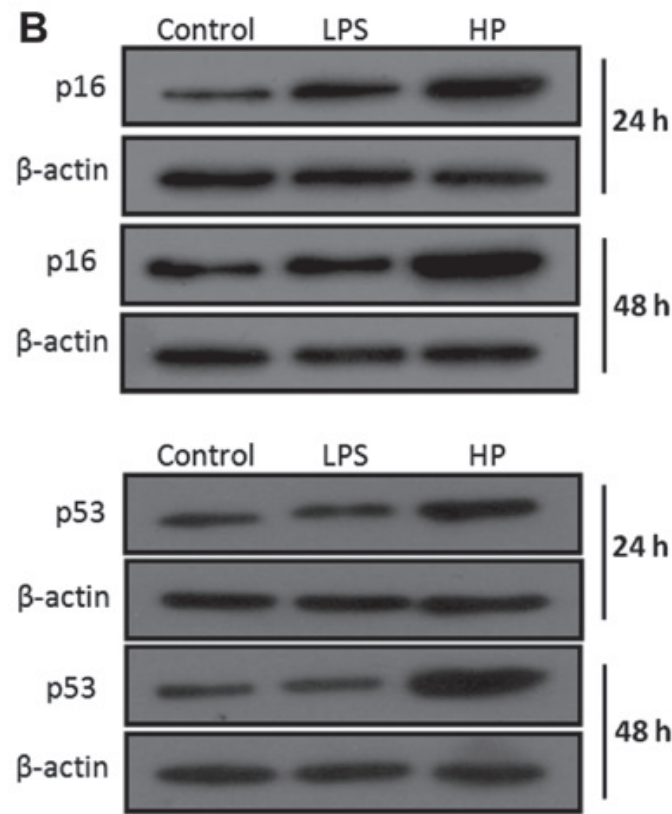
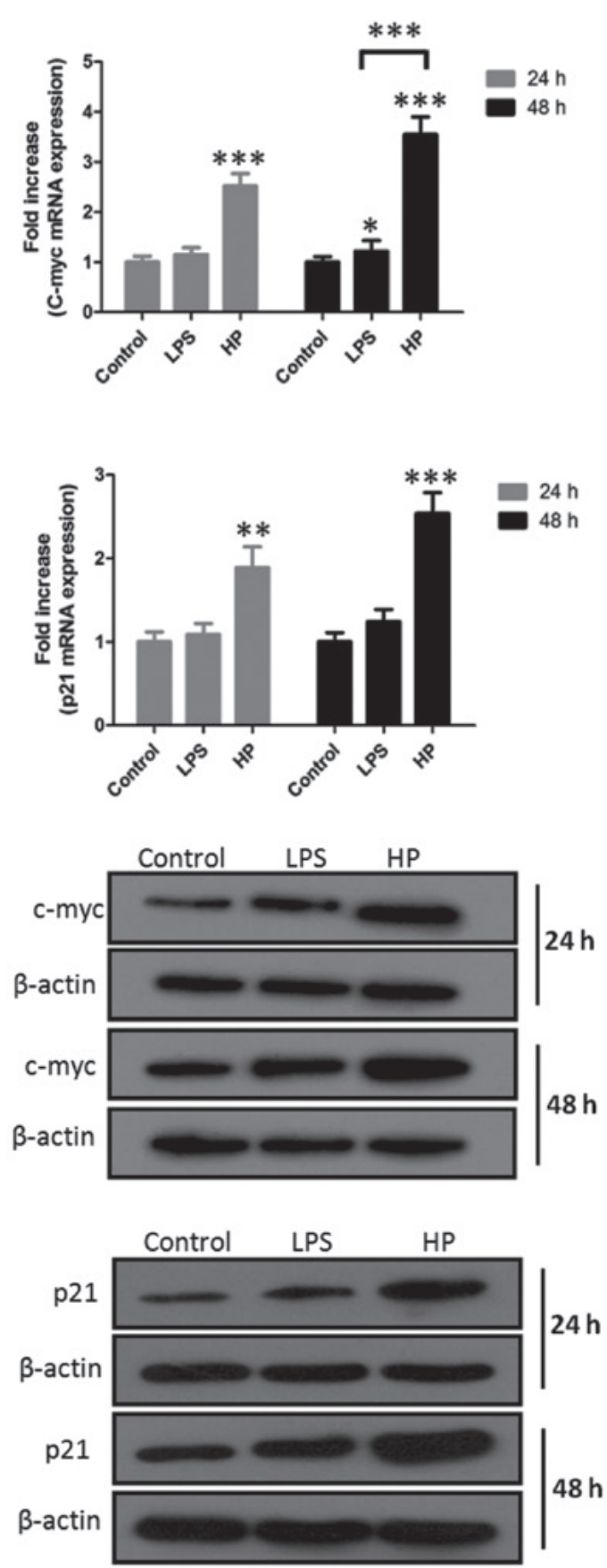

Figure 4. Cancer-associated genes and proteins p16, c-Myc, p53 and p21 in $H P$-infected GES-1 cells were analyzed by RT-qPCR and western blotting. (A) RT-qPCR results of p16, c-Myc, p53 and p21 genes. (B) Western blotting results for p16, c-Myc, p53 and p21 proteins in GES-1 cells. Quantification of p16, c-Myc, p53 and p21 expression was conducted and data are presented as the mean \pm standard error of the mean of three independent experiments $\left({ }^{*} \mathrm{P}<0.05\right.$ vs. control, ${ }^{* *} \mathrm{P}<0.01$ vs. control and ${ }^{* * * *} \mathrm{P}<0.001$ vs. control or LPS). RT-qPCR, reverse transcription-quantitative polymerase chain reaction; LPS, lipopolysaccharides; HP, Helicobacter pylori.

$H P$-infected GES-1 cells were investigated by wound-healing experiments (Fig. 5A and B) and Matrigel assay (Fig. 5C and D). As expected, the migration and invasion abilities of $H P$-infected GES-1 cells were significantly increased, compared with the control or LPS-treated groups.

Expression of CD44 and CD54 in HP-infected GES-1 cells by flow cytometry. CD44 and CD54 are associated with tumor invasion and metastasis, and are highly expressed in various malignant tumor types, including gastric cancer (19). The
CD44/54 protein expression levels in $H P$-infected GES-1 cells were quantified by flow cytometry (Fig. 6). Results demonstrated that CD44 and CD54 were upregulated in $H P$-infected cells, and that CD54 protein levels were all overexpressed.

Expression of CD44 and CD54 in $\mathrm{HP}^{+}$gastric mucosa tissues. The expression of CD44 and CD54 proteins in the tissues of different participants was quantified by IHC (Fig. 7) and it was determined that they were increased in $H P$-infected tissues. 

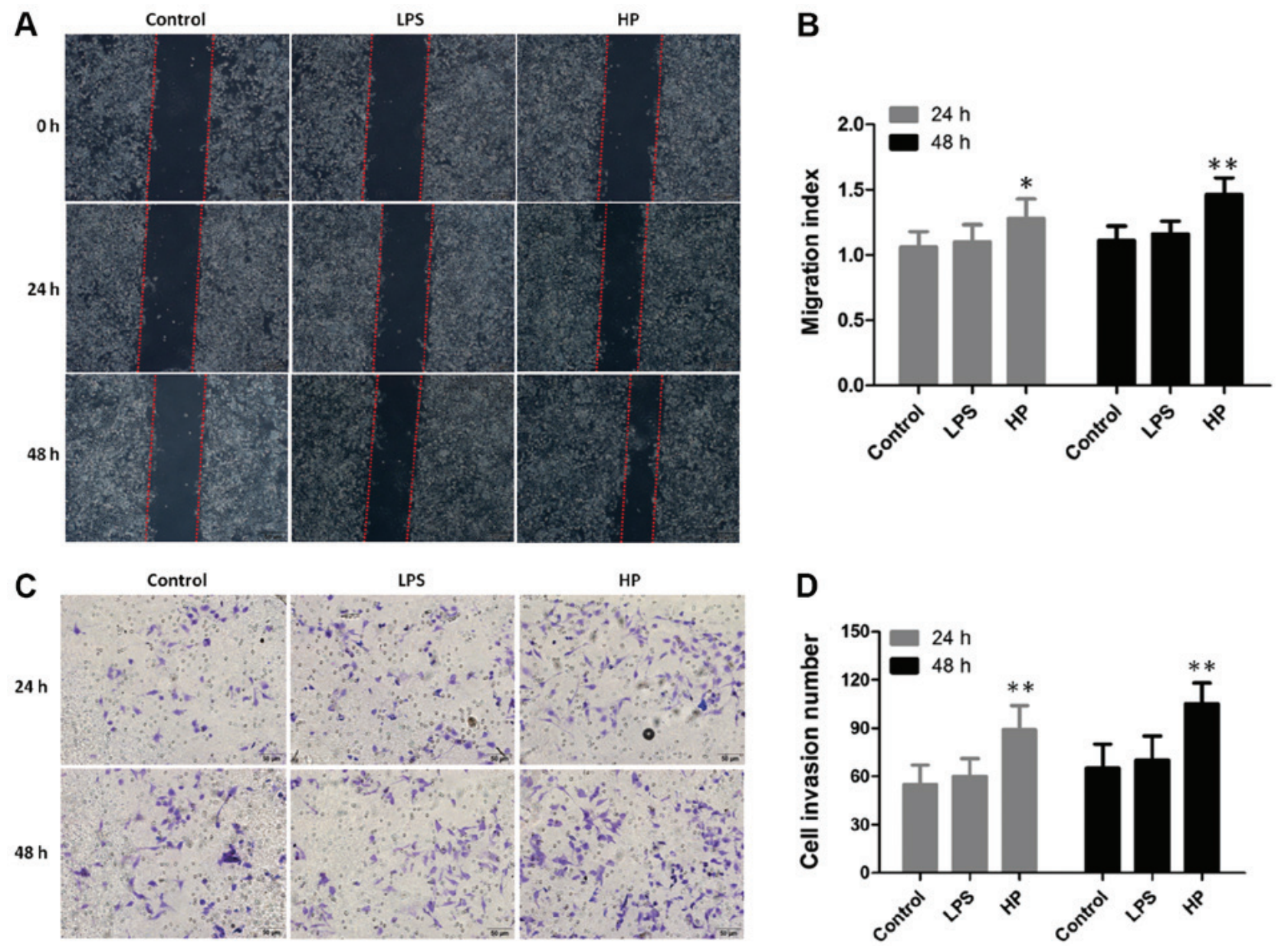

Figure 5. Migration capability analysis of HP-infected GES-1 by wound healing and Matrigel assays. (A) Wound healing data are depicted for LPS and $H P$ treatment. Scale bar, $50 \mu \mathrm{m}$. (B) Bars represent the migration index of each treatment, expressed as a value relative to the distance traveled by the cell monolayer, compared with that of control. (C) The invasion migration of GES-1 cells treated with LPS and HP. Scale bar, $50 \mu \mathrm{m}$. (D) Quantification analysis of invasion ability of GES-1 cell. Error bars represent the standard errors for three experiments carried out in triplicate ( ${ }^{*} \mathrm{P}<0.05$ vs. control and ${ }^{* *} \mathrm{P}<0.01$ vs. control). LPS, lipopolysaccharides; HP, Helicobacter pylori.

The increased CD44 and CD54 were positively associated with the severity of the disease, indicating that $H P$ infection may critically affect the expression of CD44/54.

\section{Discussion}

$H P$, a well-known gastric pathogen, can induce the generation of inflammatory factors, including IL-1 $\beta$, IL-6, IL-8, IL-23 and tumor necrosis factor- $\alpha$ (20-23), resulting in gastroduodenal inflammation, peptic ulcer disease or gastric cancer $(24,25)$. IL-8 in the gastric mucosa following $H P$ infection has been associated with the intensity of gastritis and risk of gastric cancer $(26,27)$. IL-23 generated in the gastric mucosa could imply the occurrence of chronic gastritis, and in the existence of $H P$, may be outputted from the inflammatory gastric mucosa following the kinetics of IL-1 $\beta$ (28). VacA-activated p38 signaling pathway could induce (COX-2 expression and thereby increase the formation of prostaglandin E2 (29). It was determined that IL-8 and IL-23 were markedly upregulated in $H P$-infected GES- 1 cells, causing an inflammatory response, which in turn induced the apoptosis of GES-1 cells. HP infection can increase the expression of iNOS and COX-2, which regulate cellular inflammatory responses, thereby contributing to the inflammatory response (30).
$H P$ possesses various virulence factors, including VacA and CagA, that allow it to chronically survive in the gastric mucosa (31). VacA and Cag A, two major virulence factors, have been reported to induce inflammation in the gastric mucosa and be associated with gastric cancer (32). Accumulative evidence supports CagA as a pro-oncogenic factor, and these observations are from mouse transgenic experiments, in which CagA overexpression results in uniform hypertrophy, low frequency and late onset focal tumorigenesis of the gastric epithelium, notably without significant induction of gastritis or atrophy $(33,34)$. VacA has a variety of biological activities, including the induction of apoptosis and gastric inflammation, and contribution to gastric carcinogenesis (35-37).

$H P$ upregulates the expression of p16-INK4 via its promoter in SGC-7901 cells, and activates its promoter with the involvement of specificity protein 1 (38). Telomerase mobility and c-Myc levels in gastric diseases may be affected by $H P$ infection, particularly chronic atrophic gastritis (39). Similarly, in vivo p53 expression is significantly increased in the $H P$-positive gastritis group, compared with the non-gastritis group, and the expression levels of Ki-67 and p21 were increased significantly in the $H P$-positive gastritis group $(40)$. $H P$ increases the proliferation and increases the expression of 
A
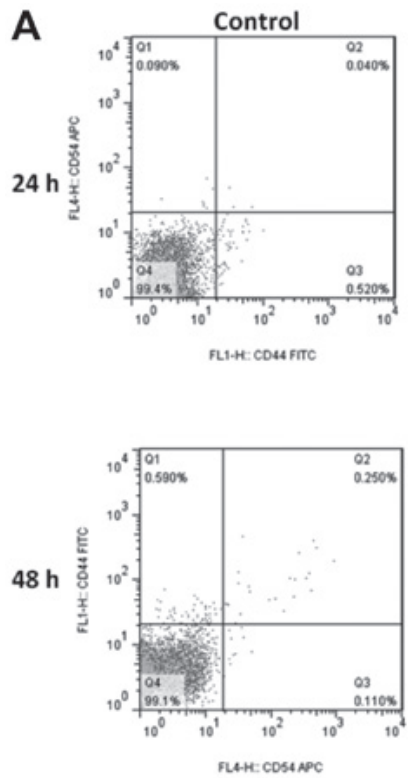
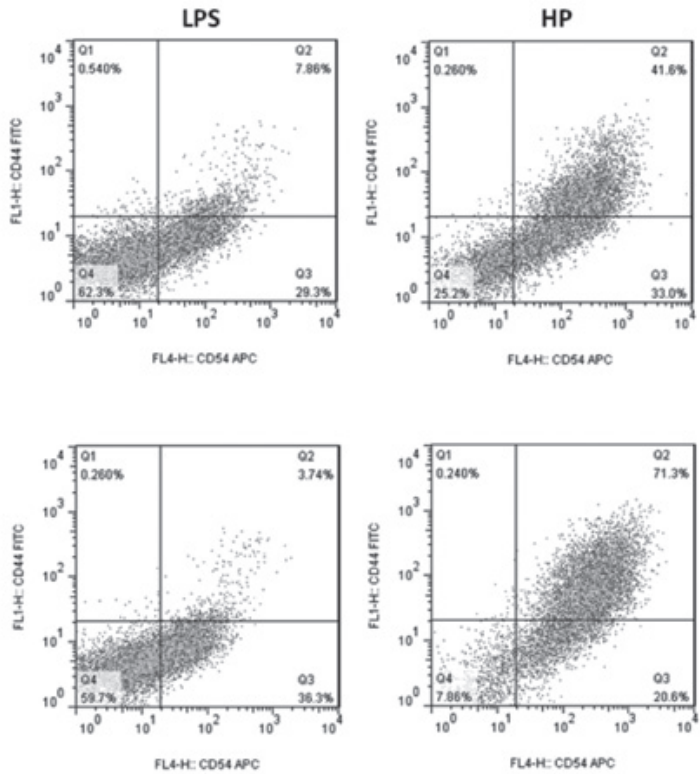

B

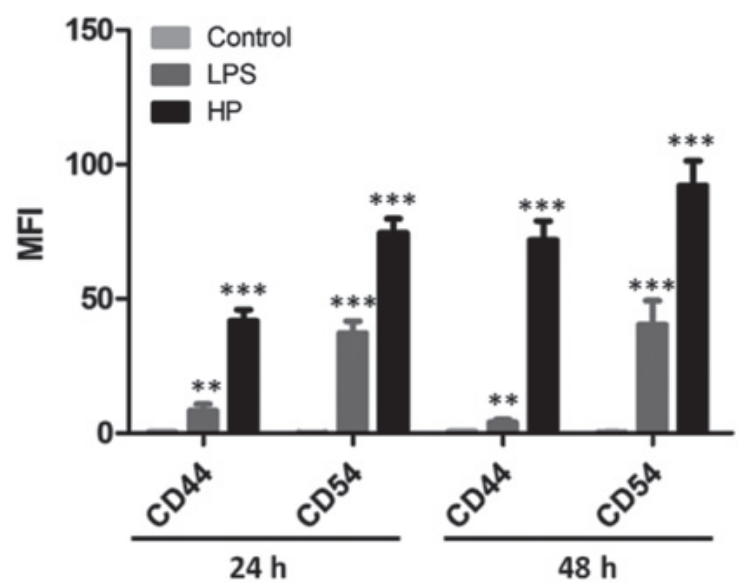

Figure 6. Analysis of CD44/54 molecules by flow cytometry in HP infection GES-1. (A) GES-1 cells treated with LPS or HP medium were analyzed on FACS and obtained fluorescence intensities of CD44/CD54. (B) Bar graphs represent the mean fluorescence intensities of CD44/54 (mean \pm standard error of the mean, 3 independent experiments), and statistical analysis was performed using SPSS $16.0{ }^{(* *} \mathrm{P}<0.01$ vs. control and ${ }^{* * * *} \mathrm{P}<0.001$ vs. control). MFI, mean fluorescence intensity; $\mathrm{CD}$, cluster of differentiation; LPS, lipopolysaccharides; HP, Helicobacter pylori.
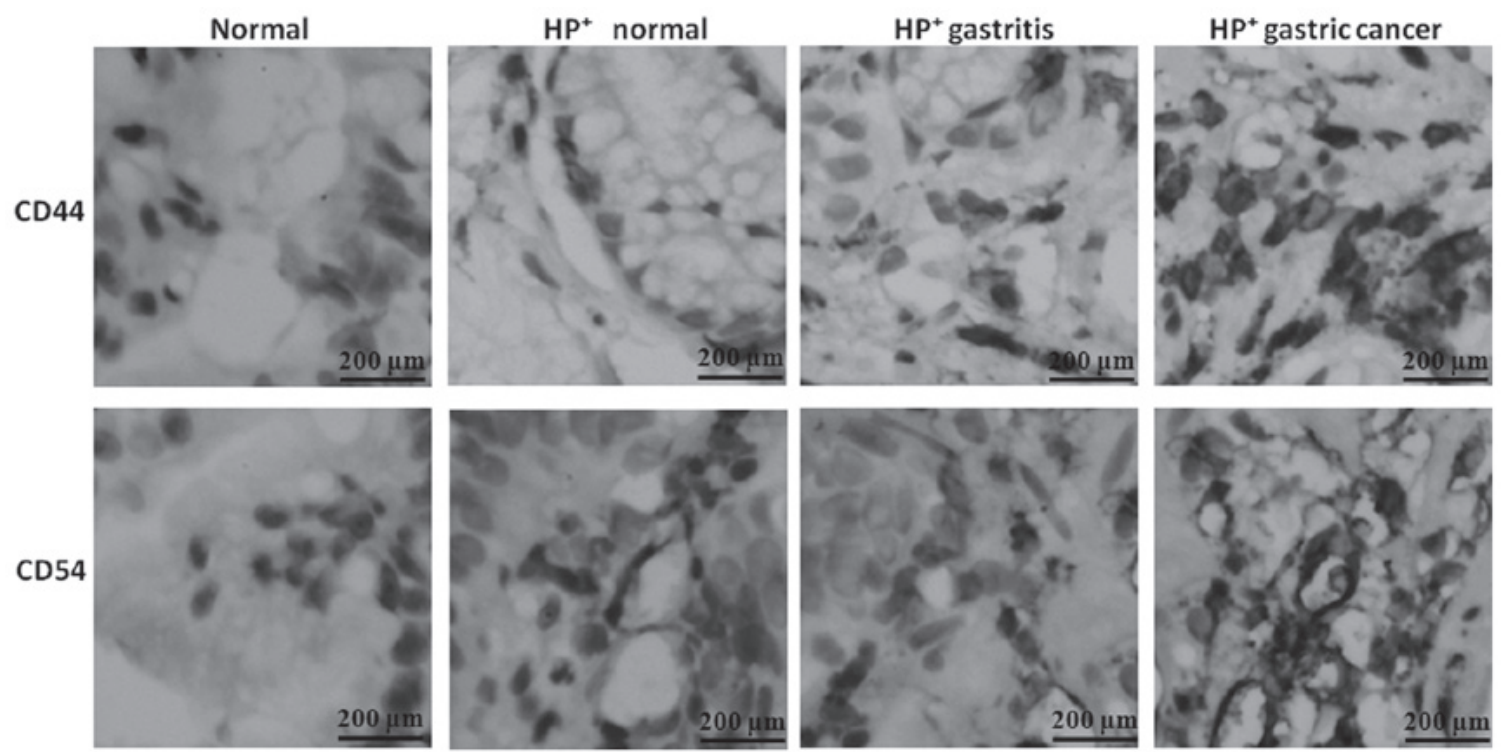

Figure 7. Immunohistochemical staining of CD44/54 in the membrane of gastric tissue cells of normal patients and patients with $H P^{+}$gastritis and $H P^{+}$gastric cancer. All pictures are in high-power fields. Scale bar, $200 \mu \mathrm{m}$. CD, cluster of differentiation; HP, Helicobacter pylori. 
p53, but not p21, in gastric mucosa, indicating that the action of p53 may be independent of p21 activity (41). In a previous study, Mongolian gerbils were infected with $H P$ for a number of hours, and HP induced an acute accumulation of p53 in the gastric mucosa, followed by a relatively low plateau for a number of weeks, and then a second peak (42). This dynamic change may depend on the balance between the p53 degradation induced by $H P$ and the intracellular self-defense mechanism. The aberrant activation of oncogenes, DNA damage and high level of inflammation induced by $H P$ may trigger the intrinsic cellular protection mechanisms, which upregulate the p53 protein (43). Notably, salt and stress synergize $H P$-induced gastric lesions, cell proliferation, and p21 expression without p53 increases in Mongolian gerbils (44). HP infection could inhibit the proliferation and induce the apoptosis of endothelial cells through increased phosphorylated p53, p21 and B-cell lymphoma 2-associated X expression, which may contribute to gastric mucosal injury and to delay healing of gastric lesions (45).

Notably, cell carcinogenesis-associated genes and proteins, including p16, c-Myc, p53 and p21, were determined to be upregulated in $H P$-infected gastric epithelial cells, and it was considered that HP induced the inflammatory response of GES-1 cells and induced the expression of p16, c-Myc, p53 and p21 in GES-1 cells at the initial stage of infection. However, as the duration of infection continues, $H P$ carcinogenic factor proteins CagA and VacA enter into host cells to activate various signaling pathways, including nuclear factor $(\mathrm{NF}-\kappa \mathrm{B}) \mathrm{NF}-\kappa \mathrm{B}$ and Janus kinase-signal transducer and activator of transcription, in cells to induce cell carcinogenesis through changing the expression of tumor suppressor genes, including p53 and p21 (46-50). Additionally, $H P$ infection significantly promoted the migration and invasion abilities of gastric epithelial cells. These changes may eventually result in inflammation-associated oncogenesis. However, further experiments are required to investigate the process of inflammation-induced carcinogenesis and its specific mechanisms.

The inflammatory events caused by $H P$ infection can contribute to gastric cancer occurrence. The circulating immune cells move to the infected mucosa via the interaction between their ligands and receptors in the endothelial zone (51). CD44, a surface marker associated with cancer stem cells, is upregulated in severe gastric lesions (52). Following co-culturing with cytotoxin-associated gene pathogen island-positive $H P$, the steady-state mRNA levels and surface CD54 in epithelial cells were upregulated. Additionally, HP stimulated the CD54 promoter via the $\mathrm{NF}-\kappa \mathrm{B}$ binding site and induced CD54 expression in gastric epithelial cells in an NF- $\mathrm{NB}$-dependent manner that may advocate leukocyte linking upon inflammation (53). CD44 and CD54 were upregulated in epithelial cells following $H P$ infection and abnormally expressed in the mucosa tissues of patients with $H P$-infected gastritis or gastric cancer.

Experiments demonstrated that the infection of $H P$ subjected normal gastric epithelial cells to significant inflammatory responses and primary cancerous reactions, indicating that $H P$ is a risk factor for gastric cancer and the inflammatory responses induced by $H P$-infection were associated with cell carcinogenesis. Nevertheless, the mechanism of carcinogenesis of gastric epithelial cells associated with the inflammation response induced by $H P$ should be further investigated.

\section{Acknowledgements}

Not applicable.

\section{Funding}

The present study was supported by grants from the science and technology development of Kunshan project (grant no. KS1717) and the Innovation Team of Kunshan First People's Hospital (grant no. KYC007).

\section{Availability of data and materials}

The datasets used and analyzed during the current study are available from the corresponding author on reasonable request.

\section{Authors' contributions}

JW and LT conceived and designed the experiments. YY and SL performed the experiments. QZ and YY analyzed the data. JW and LT drafted and revised the manuscript. All authors have read and approved the final manuscript.

\section{Ethics approval and consent to participate}

This research was approved by the Ethics Committee of Kunshan First People's Hospital, Affiliated to Jiangsu University.

\section{Patient consent for publication}

All patients whose tissues were used for immunohistochemical analysis in the present study consented to publication.

\section{Competing interests}

The authors declare that they have no competing interests.

\section{References}

1. Blaser MJ and Berg DE: Helicobacter pylori genetic diversity and risk of human disease. J Clin Invest 107: 767-773, 2001.

2. Safavi M, Sabourian R and Foroumadi A: Treatment of Helicobacter pylori infection: Current and future insights. World J Clin Cases. 4: 5-19, 2016.

3. Robinson K, Argent RH and Atherton JC: The inflammatory and immune response to Helicobacter pyloriinfection. Best Pract Res Clin Gastroenterol 21: 237-259, 2007.

4. Conteduca V, Sansonno D, Lauletta G, Russi S, Ingravallo G and Dammacco F: H. pylori infection and gastric cancer: State of the art (review). Int J Oncol 42: 5-18, 2013.

5. International Agency for Research on Cancer: IARC Monographs on the Evaluation of Carcinogenic Risk to Humans, Vol 61: Schistosomotes, Liver Flukes and Helicobacter pylori. IARC, Lyon, 1994

6. Watanabe T, Tada M, Nagai H, Sasaki S and Nakao M: Helicobacter pylori infection induces gastric cancer in mongolian gerbils. Gastroenterology 115: 642-648, 1998.

7. Honda S, Fujioka T, Tokieda M, Satoh R, Nishizono A and Nasu M: Development of Helicobacter pylori-induced gastric carcinoma in Mongolian gerbils. Cancer Res 58: 4255-4259, 1998. 
8. Franco AT,IsraelDA, Washington MK,Krishna U,Fox JG,Rogers AB, Neish AS, Collier-Hyams L, Perez-Perez GI, Hatakeyama M, et al: Activation of beta-catenin by carcinogenic Helicobacter pylori. Proc Natl Acad Sci USA 102: 10646-10651, 2005

9. Montano V, Didelot X, Foll M, Linz B, Reinhardt R, Suerbaum S, Moodley Y and Jensen JD: Worldwide population structure, long-term demography, and local adaptation of Helicobacter pylori. Genetics 200: 947-963, 2015.

10. MiszczykE,RudnickaK,Moran AP,FolM,Kowalewicz-Kulbat M, Druszczyńska M, Matusiak A, Walencka M, Rudnicka W and Chmiela M: Interaction of Helicobacter pylori with C-type lectin dendritic cell-specific ICAM grabbing nonintegrin. J Biomed Biotechnol 2012: 206463, 2012.

11. Pacifico L, Osborn JF, Tromba V, Romaggioli S, Bascetta S and Chiesa C: Helicobacter pylori infection and extragastric disorders in children: A critical update. World J Gastroenterol 20: 1379-1401, 2014.

12. Chmiela M, Gajewski A and Rudnicka K: Helicobacter pylori vs coronary heart disease - searching for connections. World J Cardiol 7: 187-203, 2015

13. Buzás GM: Metabolic consequences of Helicobacter pylori infection and eradication. World J Gastroenterol 20: 5226-5234, 2014.

14. Hu Y, He C, Liu JP, Li NS, Peng C, Yang-Ou YB, Yang XY, Lu NH and Zhu Y: Analysis of key genes and signaling pathways involved in Helicobacter pylori-associated gastric cancer based on The Cancer Genome Atlas database and RNA sequencing data. Helicobacter 23: e12530, 2018.

15. Chen S, Duan G, Zhang R and Fan Q: Helicobacter pylor cytotoxin-associated gene A protein upregulates $\alpha$-enolase expression via Src/MEK/ERK pathway: Implication for progression of gastric cancer. Int J Oncol 45: 764-770, 2014

16. Khatoon J, Prasad KN, Prakash Rai R, Ghoshal UC and Krishnani N: Association of heterogenicity of Helicobacter pylori cag pathogenicity island with peptic ulcer diseases and gastric cancer. Br J Biomed Sci 74: 121-126, 2017.

17. Livak KJ and Schmittgen TD: Analysis of relative gene expression data using real-time quantitative PCR and the $2(-\Delta \Delta \mathrm{C}(\mathrm{T}))$ Method. Methods 25: 402-408, 2001.

18. Lin SL, Yeh JL, Tsai PC, Chang TH,Huang WC, Lee ST, WasslerM, Geng YJ and Sulistyowati E: Inhibition of neointima hyperplasia, inflammation, and reactive oxygen species in balloon-injured arteries by HVJ envelope vector-mediated delivery of superoxide dismutase gene. Transl Stroke Res: Sep 6, 2018 (Epub ahead of print). doi.org/10.1007/s12975-018-0660-9.

19. Jia Q, Feng M, Wang Y and Xue S: Gastric cancer cells in collagen gel matrix: Three-dimensional growth and differential expression of adhesion molecules (CD44s, CD54, E-cadherin) J Biomed Mater Res A 84: 917-925, 2008.

20. Tafreshi M, Guan J, Gorrell RJ, Chew N, Xin Y, Deswaerte V, Rohde M, Daly RJ, Peek RM Jr, Jenkins BJ, et al: Helicobacter pylori type IV secretion system and its adhesin subunit, $\mathrm{CagL}$, mediate potent inflammatory responses in primary human endothelial cells. Front Cell Infect Microbiol 8: 22, 2018.

21. Sierra JC, Asim M, Verriere TG, Piazuelo MB, Suarez G, Romero-Gallo J, Delgado AG, Wroblewski LE, Barry DP, Peek RM Jr, et al: Epidermal growth factor receptor inhibition downregulates Helicobacter pylori-induced epithelial inflammatory responses, DNA damage and gastric carcinogenesis. Gut 67: 1247-1260, 2018.

22. Müller A and Solnick JV: Inflammation, immunity, and vaccine development for Helicobacter pylori. Helicobacter 16 (Suppl 1): 26-32, 2011.

23. Nguyen TT, Kim SJ, Park JM, Hahm KB and Lee HJ: Repressed TGF- $\beta$ signaling through CagA-Smad3 interaction as pathogenic mechanisms of Helicobacter pylori-associated gastritis. J Clin Biochem Nutr 57: 113-120, 2015.

24. Blaser MJ and Atherton JC: Helicobacter pylori persistence: Biology and disease. J Clin Invest 113: 321-333, 2004.

25. Wang J, Wu J, Cheng Y, Jiang Y and Li G: Over-expression of microRNA-223 inhibited the proinflammatory responses in Helicobacter pylori-infection macrophages by down-regulating IRAK-1. Am J Transl Res 8: 615-622, 2016.

26. Panpetch W, Spinler JK, Versalovic J and Tumwasorn S: Characterization of Lactobacillus salivarius strains B37 and B60 capable of inhibiting IL-8 production in Helicobacter pylori-stimulated gastric epithelial cells. BMC Microbiol 16: 242, 2016.

27. Chongruksut W, Limpakan Yamada S, Chakrabandhu B Ruengorn $\mathrm{C}$ and Nanta S: Correlation of Helicobacter pylori and interleukin-8 mRNA expression in high risk gastric cancer population prediction. World J Gastrointest Oncol 8: 215-221, 2016.
28. Koussoulas V, Vassiliou S, Giamarellos-Bourboulis EJ, Tassias G, Kotsaki A, Barbatzas C and Tzivras M: Implications for a role of interleukin-23 in the pathogenesis of chronic gastritis and of peptic ulcer disease. Clin Exp Immunol 156 97-101, 2009

29. Ohnishi N, Yuasa H, Tanaka S, Sawa H, Miura M, Matsui A, Higashi H, Musashi M, Iwabuchi K, Suzuki M, et al: Transgenic expression of Helicobacter pylori CagA induces gastrointestinal and hematopoietic neoplasms in mouse. Proc Natl Acad Sci USA 105: 1003-1008, 2008

30. Park HS, Wijerathne CUB, Jeong HY, Seo CS, Ha H and Kwun HJ: Gastroprotective effects of Hwanglyeonhaedok-tang against Helicobacter pylori-induced gastric cell injury. J Ethnopharmacol 216: 239-250, 2018

31. Akeel M, Shehata A, Elhafey A, Elmakki E, Aboshouk T, Ageely $\mathrm{H}$ and Mahfouz M: Helicobacter pylorivacA, cagA and iceA genotypes in dyspeptic patients from southwestern region, Saudi Arabia: distribution and association with clinical outcomes and histopathological changes. BMC Gastroenterol 19: 16, 2019.

32. Lee KS, Kalantzis A, Jackson CB, O'Connor L, Murata-Kamiya N, Hatakeyama M, Judd LM, Giraud AS, Menheniott TR. Helicobacter pyloriCagA Triggers expression of the bactericidal lectin REG3c via gastric STAT3 activation. PLoS One 7: e30786, 2012.

33. Palframan SL, Kwok T and Gabriel K: Vacuolating cytotoxin A (VacA), a key toxin for Helicobacter pylori pathogenesis. Front Cell Infect Microbiol 2: 92, 2012.

34. Raju D, Hussey S, Ang M, Terebiznik MR, Sibony M, Galindo-Mata E, Gupta V, Blanke SR, Delgado A, Romero-Gallo J, et al: Vacuolating cytotoxin and variants in Atg16L1 that disrupt autophagy promote Helicobacter pylori infection in humans. Gastroenterology 142: 1160-1171, 2012.

35. Rassow J and Meinecke M: Helicobacter pylori VacA: A new perspective on an invasive chloride channel. Microbes Infect 14: 1026-1033, 2012

36. Hisatsune J, Yamasaki E, Nakayama M, Shirasaka D, Kurazono H, Katagata Y, Inoue H, Han J, Sap J, Yahiro K, et al: Helicobacter pylori VacA enhances prostaglandin E2 production through induction of cyclooxygenase 2 expression via a p38 mitogen-activated protein kinase/activating transcription factor 2 cascade in AZ-521 cells. Infect Immun 75: 4472-4481, 2007.

37. Amieva MR and El-Omar EM: Host-bacterial interactions in Helicobacter pylori infection. Gastroenterology 134: 306-323, 2008.

38. Wang P,Mei J,Zhang N,Tao J,Tian Hand Fu GH: Helicobacterpylori upregulates the expression of p16(INK4) in gastric cancer cells. Hepatogastroenterology 58: 846-853, 2011.

39. Zhang GX, Gu YH, Zhao ZQ, Xu SF, Zhang HJ, Wang HD and Hao B: Coordinate increase of telomerase activity and c-Myc expression in Helicobacter pylori-associated gastric diseases. World J Gastroenterol 10: 1759-1762, 2004.

40. Saf C, Gulcan EM, Ozkan F, Cobanoglu Saf SP and Vitrinel A: Assessment of p21, p53 expression, and Ki-67 proliferative activities in the gastric mucosa of children with Helicobacter pylori gastritis. Eur J Gastroenterol Hepatol 27: 155-161, 2015.

41. Petersson F, Franzén LE and Borch K: Characterization of the gastric cardia in volunteers from the general population. Type of mucosa, Helicobacter pylori infection, inflammation, mucosal proliferative activity, p53 and p21 expression, and relations to gastritis. Dig Dis Sci 55: 46-53, 2010.

42. Wei J, Nagy TA, Vilgelm A, Zaika E, Ogden SR, Romero-Gallo J, Piazuelo MB, Correa P, Washington MK, El-Rifai W, et al: Regulation of p53 tumor suppressor by Helicobacter pylori in gastric epithelial cells. Gastroenterology 139: 1333-1343, 2010.

43. Xu H, Chaturvedi R, Cheng Y, Bussiere FI, Asim M, Yao MD Potosky D, Meltzer SJ, Rhee JG, Kim SS, et al: Spermine oxidation induced by Helicobacter pylori results in apoptosis and DNA damage: Implications for gastric carcinogenesis. Cancer Res 64: 8521-8525, 2004.

44. Gamboa-Dominguez A, Ubbelohde T, Saqui-Salces M, Romano-Mazzoti L, Cervantes M, Domínguez-Fonseca C, de la Luz Estreber M and Ruíz-Palacios GM: Salt and stress synergize $H$. pylori-induced gastric lesions, cell proliferation, and $\mathrm{p} 21$ expression in Mongolian gerbils. Dig Dis Sci 52: 1517-1526, 2007.

45. Kurosawa A, Miwa H, Hirose M, Tsune I, Nagahara A and Sato N: Inhibition of cell proliferation and induction of apoptosis by Helicobacter pylori through increased phosphorylated p53, p21 and Bax expression in endothelial cells. J Med Microbiol 51: 385-391, 2002 . 
46. Suzuki M, Mimuro H, Kiga K, Fukumatsu M, Ishijima N Morikawa H, Nagai S, Koyasu S, Gilman RH, Kersulyte D, et al: Helicobacter pylori CagA phosphorylation-independent function in epithelial proliferation and inflammation. Cell Host Microbe 5: 23-34, 2009.

47. Murata-Kamiya N, Kurashima Y, Teishikata Y, Yamahashi Y, Saito Y, Higashi H, Aburatani H, Akiyama T, Peek RM Jr, Azuma T, et al: Helicobacter pylori CagA interacts with E-cadherin and deregulates the beta-catenin signal that promotes intestinal transdifferentiation in gastric epithelial cells. Oncogene 26: 4617-4626, 2007.

48. Gagnaire A, Nadel B, Raoult D, Neefjes J and Gorvel JP: Collateral damage: Insights into bacterial mechanisms that predispose host cells to cancer. Nat Rev Microbiol 15: 109-128, 2017.

49. Chauhan N, Tay ACY,Marshall BJ and Jain U: Helicobacter pylori VacA, a distinct toxin exerts diverse functionalities in numerous cells: An overview. Helicobacter 24: e12544, 2019.

50. Kumar S and Dhiman M: Inflammasome activation and regulation during Helicobacter pylori pathogenesis. Microb Pathog 125: 468-474, 2018
51. Lundgren A, Trollmo C, Edebo A, Svennerholm AM and Lundin BS: Helicobacter pylori-specific $\mathrm{CD}^{+}{ }^{+} \mathrm{T}$ cells home to and accumulate in the human Helicobacter pylori-infected gastric mucosa. Infect Immun 73: 5612-5619, 2005.

52. Garay J, Piazuelo MB, Majumdar S, Li L, Trillo-Tinoco J, Del Valle L, Schneider BG, Delgado AG, Wilson KT, Correa P, et al: The homing receptor CD44 is involved in the progression of precancerous gastric lesions in patients infected with Helicobacter pylori and in development of mucous metaplasia in mice. Cancer Lett 371: 90-98, 2016.

53. Maeda S, Akanuma M, Mitsuno Y, Hirata Y, Ogura K, Yoshida H, Shiratori Y and Omata M: Distinct mechanism of Helicobacter pylori-mediated NF-kappa B activation between gastric cancer cells and monocytic cells. J Biol Chem 276: 44856-44864, 2001 